\title{
The Hadith Perspective on Educational Funding
}

\author{
Maslani, Ratu Suntiah, Yasniwarti, Ujang Dedih \\ Department of Islamic Education \\ UIN Sunan Gunung Djati \\ Bandung, Indonesia \\ maslani@uinsgd.ac.id, ratusuntiah@uinsgd.ac.id, yasniwarti@uinsgd.ac.id,ujangdedih@uinsgd.ac.id
}

\begin{abstract}
Educational funding is the provision of the necessary financial resources for the administration and management of education. The purpose of this study is to analyse and find the hadith perspective on educational funding. The analysis used in the discussion of this article is a qualitative analysis with causal analysis approach. The use of this method is to look at causal relationship between variables, which are processed based on the results of observations, interviews, and the compatibility of theoretical basis with existing libraries. This research was conducted at the Islamic Boarding School in Cirebon. The unit of analysis used in this article is the educational institution based on the respondent's perspective. In conclusion, there is no absolute and unequivocal prohibition in the system of salary, honorarium, and wages in education and teaching. It, however, depends on the existing conditions. AlBukhari himself narrated that the hadith with several similar texts indicated the existence of the inclination of receiving salary or salary in the teaching of the Qur'an.
\end{abstract}

\section{Keywords-educational funding; hadith perspective}

\section{INTRODUCTION}

Educational funding is extremely vital in the implementation of education, because all the activities conducted require organization with adequate financial condition. Funding in this context is in the form of money or goods in order to support educational process. The comprehensive and professional management to existing resources within the institution should be carried out as efforts to realize a quality education. One of resources that must be managed well in Islamic education is financial sector. In this context funding constitutes the source of fund greatly required by school as the instrument to complete various learning facilities in Islamic school, to increase teacher's prospurity, service, and the implementation of supervision program [1]. Educational funding is provision of financial resource needed for educational administration and management. Funding (cost) in this term has a wide scope namely all sorts of expenditures related to educational administration, either in the form of money or goods and energy that can be priced with money. In this sense, for example, student's fee is obviously a funding, but physical facilities, school books and teachers are also funding. How the funding is planned, acquired, allocated and managed is an educational funding issue (educational finance) $[1,2]$.

The government establishes the national standard of education one of which is the cost standard of education in addition to seven other standards supporting the implementation of education well and smoothly. The variable of content standard, personnel, facilities and infrastructure, financing, management, and appraisal, have positive relation which varies to variable of process standard and graduate competence. Therefore, financing standard needs to be noticed besides the amount of required quantity and financial management, so that those all can be used properly, effectively and efficiently [3, 4]. The cost standard certainly needs managing well in order that it does not hamper the implementation of other activities. The educational cost or funding is not everything but it is urgently needed $[1,5,6]$. The sources of educational funding can not be charged only to a party. Through school operational assistance the government provides funding support of educational administration to relieve the burden of schools and parents and to improve the quality of education [7, 8]. The fund granted by the government has not been able to meet the overall school activities especially in Islamic Schools (Madrasah) mostly belonging to the community or private sector. The dependence of Islamic School on educational funding is immensely high. The efforts to advance education can not run on one side, but all elements of the community must help in the implementation of education. All educational funds should not be charged to the government due to limited educational budget which is not comparable with the number of schools or madrasah. The community through school committees helps in the educational administration through educational grants sourced from student's parents. The poor students are freed from the fundraising action and it does not burden the community [2, 8, 9].

Basically in hadith perspective there is no absolute prohibition on funding's, the system of salaries, honorariums, and wages in education and teaching, but it depends on the condition faced. Al-Bukhari, himself, narrated the hadith related to funding with several similar texts indicating the tendency of leniency toward receiving a salary or honorarium in the teachings of the Qur'an $[10,11]$. The purpose of the research is to know the view of hadith about educational funding; to know the sources of educational funding; and to know principles of educational funding.

\section{METHOD}

The method used in this research is a qualitative analysis with causal-effectual analysis approach. The use of this method is to look at causal-effectual relationships among variables 
processed based on the result of observation, interview, and the compatibility of theoretical foundations with existing literature. This research was conducted at the Islamic Boarding School in Cirebon. The Analysis used in this article is the educational institution based on the respondent's perspective [12].

\section{RESULTS AND DISCUSSION}

\section{A. Educational Funding}

Educational funding is one of the instrumental input components (input instruments) that are very important in the implementation of education in every effort of educational achievement either for quantitative or qualitative goals. Educational funding has a very decisive role. There is hardly any educational effort ignoring the role of funding, so that it can be stated that without funding the educational process will not work well. The availability of fund is needed with the purpose for procurement of learning tools, teacher and employee salaries, equipment maintenance and other operational costs. The hadith of Messenger of Allah (Rasulullah) explained there was one of the Prophet's companions going to a place and he recited al-fatihah with the reward of a goat. Apparently the stung person was healed. Then, he brought the goat to his friends. However, his friends did not like it, they said; "Did you take a reward for book of Allah (kitabullah)?" after they arrived in Medina, they said; "O Messenger of Allah, he took wages upon kitabullah." Then, the Messenger of Allah (peace and blessings of Allah be upon him) said: "Verily the most rewarding wage you took was the reward for (teaching) the Book of Allah (kitabullah)." (Narrated by Al Bukhori).

The hadith is one of the sources of educational funding reference, namely a teacher may receive wages. The above hadith provides the motivation that teacher or educator may receive wages. Meanwhile, treatment by reciting verses from the Qur'an is also allowed. The background (asbabul wurud) of the hadith above is when a group of companions of the massanger of Allah passed people who lived in the place where water fell down. There was a shocking event when a venomous animal (perhaps a snake and possibly a scorpion) in the water bit one of them.

Then, they asked for help to the Prophet's companions to cure him. One of them asked: was there any of you who could cure a sick person who was bitten by a venomous animal? One of the companions of the prophet set out to treat him by reciting al-fatihah. By will of Allah, the one bitten by the venomous beast could be healed and the companion of prophet was given the reward namely a sheep.

\section{B. Sharah Hadith}

When he accepted the reward, the companions responded him negatively and he was not allowed to accept the reward as if he sold the Qur'anic verse by accepting the wage of a sheep. In the al A'masy's narration besides al-Turmudzi's it was stated that there were 30 companions who were sent by the Prophet at night passing through a village. It was not clear what the name of the village was. In this context the representatives were not in the mission of earnestly doing effort carried out by knowledgeable figure to decide a case not discussed in the Qur'an and hadith using common sense and careful consideration (ijtihad). When associated with education, there are certainly many differences related to the number of wages or salaries accepted. As Al-'Asqhalany revealed in Fath alBariy (4): 453, there were some scholar's (Ulama) opinions in the system of accepting salary, honorarium, or wage in education and teaching: the Jumhul ulama allowed teachers to accept wages in teaching based on the above hadith; The Hanfiyah ulama prohibited the acceptance of wages in teaching and permitted them only for treatment or ruqiyah. The reason was because teaching the Qur'an was worship and the reward came from Allah. The permissibility of accepting wages in ruqiyah was coming from the hadith above.

Then, sheikh 'Athyan Muhammad Salim in Sharah Bhulugul al-Marram, explained that based on the hadith above there were several opinions related the law of receiving a wage or salary in the teaching of the Qur'an or reading it. They were: if the giving of wage or salary was from the will of the person taught, it was permissible; if the wage or salary was paid due to teaching or reading the Qur'an not from the person taught, it was not allowed. In conclusion, there is no absolute and unequivocal prohibition in the system of receiving salary, honorarium, and wage in education and teaching. It depends on the condition faced. Al-Bukhari, himself, narrated the hadith with several similar texts indicating the tendency of permissibility of receiving salary or honorarium in the teaching of the Qur'an [10].

In the theory and practice either in the macro or micro level, there are several categories of educational funding. The first is direct and indirect funding. Direct funding is any expenditure that directly supports the implementation of education. Indirect funding is the expenditures that do not directly support the educational process but it enables the educational process occurring at school, for example student living cost, transportation cost, pocket cost, health cost, and opportunity cost. The second is private fundng and social funding. Private funding is family expenditure for education. It is also known as household expenditure. Social funding is the cost that people spend on education, either through schools or taxes collected by government then used to fund education. The funding for education basically belongs to social funding. The third is monetary funding and non-Monetary funding [1].

\section{Educational Funding Sources}

Yahya bin Yahya At Tamimi had revealed to us, Sulaim bin Ahdlar from Ibn 'Aun from Nafi' from Ibn Umar had stated, "Umar got a part of the estate land in Khaibar. Then, he came to the Prophet sallallaahu 'alaihi wasallam and asked for advice regarding that plantation land. He said, "O messenger of Allah, I got a portion of estate land in Khaibar, and I had never obtained the treasures I was so proud of as the garden, so what would you command about the garden?" he replied: "If you would, take care of the tree and give the yield away." Ibn Umar said, "Then Umar gave the yield away, he did not sell the tree and the yield, it was not inherited and not granted." Ibn Umar continued, "Umar gave the yield to the poor, relatives and colleagues, the liberation of the slave, the fund of struggle in the way of Allah, to the warriors and to serve the guests. He 
also allowed others to cultivate the garden and to eat the yield properly, or to feed their friends by not keeping the yield." Ibn Umar said again, "And I had told this hadith to Muhammad, when I came to the statement, 'And not to keep it', then Muhammad said," And do not gather the wealth. "Ibn 'Aun said, "And the one who had read this book had proclaimed to me, that it was written inside, 'And not to gather the treasure.' And Abu Bakr ibn Abu Shyaibah had told us and Ibn Abu Zaydah had said to us.

It was mentioned in other source that Ishaq had told us, Azhar As Saman had said to us. (It was mentioned in another line) Muhammad bin Al Mutsanna had conveyed to us, Ibn Abu 'Adi had told us everything from Ibnu' Aun with these sanads, but hadith from Ibn Abu Zaida and Azhar finished on lafadz (the statement), 'or to feed to his friends without keeping it ', and something else was not mentioned afterwards. Besides, the hadith from Ibn Abu 'Adi, inside of the hadith as mentioned by Sulaim, namely Ibn 'Umar's statement, 'Then I conveyed this hadith to Muhammad' and so on. "And Ishaq bin Ibrahim had told us, Abu Daud Al Hafari Umar ibn Sa'd had said to us from Sufyan from Ibn 'Aun from Nafi' from Ibn Umar from Umar that, "I got a part of estate land in Khaibar, then I saw the Prophet peace and blessings of Allah be upon him saying, "I obtained the land of plantation, and there was nothing I prefer besides the land .... Then he continued the hadith as they all had, but he did not mention "Then I conveyed this hadith to Muhammad', and afterwards."

Umar ibn al-Khattab got land in Khaibar, which was a hundred dirhams in amount, and it was his most valuable treasure. Moreover it was a fertile land. Therefore people competed to own the land. Then, 'Umar met the messenger of Allah (peace and blessings of Allah be upon him) because he was encouraged to gain virtue. 'Umar saw the messenger of Allah to ask his opinion on the matter of giving a charity of the land, for he believed in the perfection of his advice. The messenger of Allah gave the best way to manage and use the wealth by means of charity, namely by retaining the land and making the land used for the public, so that the land could not be sold, awarded, inherited or anythingelse and various kinds of commerce, because of which the property of the land would switch. On the contrary the land should be used to give a living to the poor, relatives in blood relation, to free the slave, or pay fines for those who bear the burden of kifarat, help those who struggled in the way of Allah, glorify His sentence of oneness and help His religion, feed the strangers (not from the country concerned) who traveled and ran out of the expense, or feed his guests because respecting the guests included the branch of faith to God. Similarly, people who took care of the land were also allowed to take for the purpose of fulfillment of his and his colleague's consumption as needed without intending to pile up the wealth.

\section{Explanation / Avail of Hadith}

In educational funding there are several sources of educational cost to support the implementation process of education. The source of educational funding comes from the central government, local government, as well as both of them. It is general and specific and is intended for educational purposes. Government is responsible for funding education by allocating educational budget to state budget and regional budget. Constitution number 20 year 2003 on National Education System Section 49 mandates that educational funds other than educators' salaries and official educational expenses are allocated at least $20 \%$ of the State Budget (APBN) to the educational sector and at least $20 \%$ of the Regional Budget (APBD). Unfortunately, this mandate is countered by the decision of the Constitutional Court Number 13 / PUU-VI I 2008 , the educational budget at least $20 \%$ of the APBN and APBD, including teachers' salaries, parents, students and the community [13].

Furthermore, the expenditure dimension includes routine funding and development financing. Routine funding is funding that must be spent from year to year such as salary of employees, (teacher and non-teacher), as well as operational funding, building maintenance funding, facilities, and teaching equipment (consumables). Meanwhile, development funding, for example, maintenance funding or renovation of building, the addition of furniture, as well as funding or other expenditures for consumables [14]. Being seen in terms of the use, the source of funding can be divided into two types, namely budget for routine activities, i.e. salary and funding for daily school operations and budget for school development [9]. Then, Abudin Nata in the History of Islamic Education said that the source of educational funding in the classical period, namely:

\section{1) Government / State Subsidies}

Muslim rulers and leaders had great attention to science since the era of the khulafaur Rashidin. They built and supported various facilities of science and education, including the institutions such as assuffah, mosques, Islamic schools (madrasah) and so on.

\section{2) Waqf}

Waqf is part of worship and Islamic law related to property. One of the parts of educational funding system, waqf, became a well-organized institution and a mode in the Abbasiyah's period especially in the golden age of Islamic civilization. There were many educational institutions endowed by waqf in the era of classical Islam, for example, Badr Ibn Hasanawih AlKurdi, a wealthy nobleman who became a governor, founded 3000 mosques with an academy inside. Each mosque had a Khan Mosque dormitory [8].

\section{3) Parents}

The educational cost sourced from parents considerably varies and is very flexible depending on parents' financial condition. This cost also reflects students' progress, because in addition to the registration fee, additional fees will be asked when the students have completed a certain level of lessons, added with nonfinancial contribution, such as food and clothing according to students' family condition. A scientist who teaches in mosques, madrasah or other educational institutions is allowed to collect money from his students. Usually the amount is approved by the teacher and the students and it is paid at the beginning of the learning period. Ibrahim Al-Zadjdjadj, for example, earns 1.5 dirhams per day from his work. Then, he studies to Al-Mubarrid and pays the fee twothirds of his income, added with another syariat, namely 1 durham every day until the death separates them [10]. 


\section{4) Other Resources / Individual}

The view that the religious science, especially the Qur'an should be taught to others as a form of worship, encourages the teachers not to ask and receive financial assistance from anyone. They strive to finance their educational activities and life only from the results of their hard work aside from teaching. Based on the description, it can be concluded that the source of education in the present and classical period has the same sources. They are government, parents, students and society (other sources). The difference is in the system and the rules of the government.

\section{E. Principles of Educational Funding Management}

The first hadith explains that in the essence all human beings are leaders for everything under their authority according to their level and position either formal leaders or non-formal leaders. Each leader will be asked for his responsibility from what he leads. The imam is the leader who will be asked for his responsibility for his people. A husband is a leader and he will be asked for his responsibility for his family. A wife is a leader in her husband's household affairs, and she will be asked for her responsibility for the household affairs. This is the description of the Prophet Muhammad in his words as mentioned in the hadith above. Thus, everyone should be responsible for his responsibility. Likewise, the government has a very big responsibility for education in a country based on the mandate and constitution applicable in the country. Education is not just the responsibility of government, but it is a shared responsibility, especially for the teacher as an educator who educates his students [5, 7]

The form of funding certainly becomes an important thing in running an educational process [15], because without any funding in the educational process, the process of education will surely not work well. Therefore, the managers of educational institutions should pay attention to the principles in managing educational funding. Educational funding management is based on the principles of efficiency, transparency, and public accountability. The four principles will be described below:

\section{1) Transparency}

Transparent means the openness of the source of funds and the amount, the details of use, and the clarity of accountability. It enables the interested parties to know anything related to the funds exactly. Some of the financial information freely known by all school communities and students' parents such as school budget plan of income and expenditure $(R A P B S)$ can be sticked on bulletin boards in teacher's office or in front of the administrative room, so that anyone who needs the information can easily get it. Students' parents can know how much money the school receives from students' parents and what the money is used for.

\section{2) Accountability}

Accountability is the condition of a person who is judged by others due to the quality of his performance in completing the task to achieve the objectives he is responsible for. The use of educational funds can be accounted for in accordance with the planning that has been set. There are three major pillars becoming prerequisites for accountability development, namely
(1) the existence of transparency of educational organizer by accepting inputs and involving various components in managing education, (2) the existence of performance standards in each institution that can be measured in performing the duty, function and authority, (3) the existence of participation to create a mutual conducive atmosphere in creating community service with easy procedures, low cost and fast service.

\section{3) Effectiveness}

Effectiveness emphasizes the qualitative outcomes of an activity. The management of educational fund has fulfilled the principle of effectiveness if the activities undertaken can allocate the available funds to finance the activities in order to achieve the objectives of the institution and the qualitative outcomes is appropriate with the plan established.

\section{4) Efficiency}

Efficiency has more emphasis on the quantity of results of an activity. Efficiency is the best comparison between input (input) and output (output) or between effort and result. The effort concerned includes energy, mind, time, and cost. The comparison can be seen from two respects. In the aspect of the use of time, energy and cost, the management of educational funds is efficient if the use of little time, energy and cost can achieve the results established. From the aspect of results, the activity of managing educational funds is efficient if the use of time, energy and costs can give maximal results both quantity and quality.

\section{CONCLUSION}

Educational funding as a financial resource is required for educational implementation and management. Islamic boarding school has not fully had standardization of funding either a source of income or good management in financial administration. The funding obtained must be managed and accounted for the government and society as contributors to education. Based on the hadith of Bukhori explaining that teacher is permissible to receive wages for he has performed his duties as a teacher and to obtain educational funding from students' parents. Educational Funding is free for the students. This model is well known in education conducted by the Bedouins by asking for funds to the learners. The sources of education in the present and classical period are the same, namely government, parents and the community as the other source. The difference is in the system and the rules of the government. The management of educational funding is based on the principles of efficiency, transparency, and public accountability. The four principles are briefly described below: transparency of accountability; effectiveness; efficiency.

\section{ACKNOWLEDGMENT}

Our thanks are conveyed to the dean of the Faculty of Tarbiyah and Teacher Training for the help and facilities given in ICIE administered by the Faculty of Tarbiyah and Teacher Training State Islamic University Sunan Gunung Djati Bandung. 


\section{REFERENCES}

[1] D. Supriyadi, Satuan Pendanaan Pendidikan Dasar dan Menengah, Bandung: PT. Remaja Rosda Karya, 2006.

[2] M. Pidarta, Perencanaan Pendidikan Partisipatori dengan Pendekatan sistem, Jakarta: Asri Mahasatya, 2005.

[3] S.B. Raharjo, "Quality Evaluation Of Education Trend In Indonesia," Jurnal Penelitian dan Evaluasi Pendidikan, vol. 16, no. 2, p. 511, 2012.

[4] T.H.A.R, Manajemen Pendidikan Nasional: Kajian Pendidikan Masa Depan, Bandung, 2006.

[5] D. Wijaya, "Manajemen Sumber Daya Manusia Pendidikan Berbasis Kompetensi Guru dalam Rangka Membangun Keunggulan Bersaing Sekolah," Jurnal Pendidikan Penabur, vol. 12, no. 8, p. 84, 2009.

[6] N.C.o. Educational, Basic in Education, Newdelhi: Publication Divsion by the Secretary, National Council of Educational Research and Training, Sri Aurobindo Marg, 2014.
[7] F.J.d.D. Supriadi, Reformasi Pendidikan dalam Konteks Otonomi Daerah, Yogyakarta: Adi Citra, 2001.

[8] S.H.S.d.A. Iqbal, "Accountability The Endless Prophecy," Asian and Pacipic Development Centre, 1995.

[9] M. Qomar, Manajemen Pendidikan Islam, Surbaya: Erlangga, 2007.

[10] A. Tafsir, Ilmu Pendidikan Islam, Bandung: Rosdakarya, 2015, p. 150.

[11] K. Saleemad, "Leadership Competency Model For Islamic School Leaders," International Journal of Humanities and Management Sciences (IJHMS), vol. 3, no. 2, p. 86, 2015

[12] C.B.a.S. Taylor, Introduction in Qualitative Research Methods, New York: John Wiley and Son Inc, 1995.

[13] A.M. Khon, "http// pendanaan/Tentang Pendanaan Pendidikan_tentang pendidikan.htm:," 2012.

[14] D. Jamaludin, Pembelajaran Perspektif Islam, Bandung: PT. Remaja Rosdakarya, 2015.

[15] Sulistyorini, Manajemen Pendidikan Islam, Surabaya: eIKAF, 2006. 